[Agr. Biol. Chem., Vol. 36, No. 11, p. 2041 2043, 1972]

\title{
Effect of Pepsin Inhibitor (S-PI) on the Growth of Rhodotorula glutinis No. K-24
}

Sir:

Pepsin inhibitor (S-PI), produced by Streptomyces naniwaensis, was found to be an acylpentapeptide with MW $643 .^{1 \sim^{4}}$ It inhibited not only pepsin but also acid proteases that are widely produced by various yeasts and fungi, by the formation of a protease-inhibitor complex. The authors intend to make use of S-PI, and therefore aerobically cultured an acid protease producing organism, Rhodotorula glutinis No. $\mathrm{K}-24,{ }^{5}$ ) in the presence $(6 \sim 120 \mu \mathrm{g}$ per $\mathrm{ml})$ or absence of S-PI at various temperatures for $92 \mathrm{hr}$ in a medium

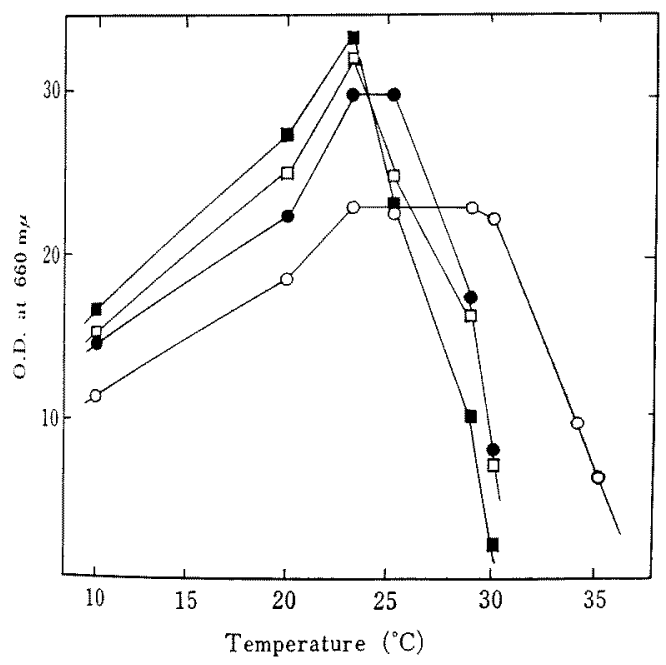

Fig. 1. Effect of S-PI on the Growth of Rhodotorula glutinis No. $\mathrm{K}-24$.

The yeast cells were cultured for $96 \mathrm{hr}$ at each temperature and the optical density at $660 \mathrm{~m} \mu$ was measured.

O-O $0 \mathrm{mg} \mathrm{S}-\mathrm{PI} / 100 \mathrm{ml}$, $-0.6 \mathrm{mg} \mathrm{S}-\mathrm{PI} /$ $100 \mathrm{ml}, \square-\square 1.2 \mathrm{mg}$ S-PI $/ 100 \mathrm{ml}$, $6.0 \sim$ $12.0 \mathrm{mg} \mathrm{S}-\mathrm{PI} / 100 \mathrm{ml}$. of initial $\mathrm{pH} 2.8$, containing $7 \%$ glucose, $2 \%$ polypetone, $0.6 \% \mathrm{KH}_{2} \mathrm{PO}_{4}, 0.8 \% \mathrm{MgSO}_{4}$. $7 \mathrm{H}_{2} \mathrm{O}, 4 \mathrm{ppm} \mathrm{MnSO}_{4} \cdot 6 \mathrm{H}_{2} \mathrm{O}, 4 \mathrm{ppm} \mathrm{FeSO}_{4}$. $7 \mathrm{H}_{2} \mathrm{O}$ and $2 \mathrm{ppm}$ thiamine $\mathrm{HCl}$. The growth was determined by measuring optical density at $660 \mathrm{~m} \mu$, as shown in Fig. 1 .

An optimal growth temperature under normal conditions, without S-PI, was found to be $23 \sim 30^{\circ} \mathrm{C}$ with a maximum around $37^{\circ} \mathrm{C}$. In contrast, the maximum growth temperature in the presence of S-PI decreased with increasing concentrations of S-PI. It was found to be $30^{\circ} \mathrm{C}$ at a concentration of $120 \mu \mathrm{g}$ per $\mathrm{ml}, 7^{\circ} \mathrm{C}$ lower than that without S-PI. At temperatures lower than $25^{\circ} \mathrm{C}$, on the other hand, the growth of the yeast increased proportionally with increasing concentrations of S-PI. The optimal growth temperature was $23^{\circ} \mathrm{C}$ at $60 \sim 120 \mu \mathrm{g}$ per $\mathrm{ml}$. At this concentration of S-PI, the growth was 1.4 times greater than that of the control. Thus, S-PI did inhibit growth at higher temperatures, but acceralated it at lower temperatures. The growth inhibition of S-PI at higher temperatures was eliminated by addition of calcium chloride and amino acids mixture, as shown in Fig. 2. The yeast growth at $30^{\circ} \mathrm{C}$ in the presence of S-PI was restored by addition of calcium chloride to $60 \%$ that of the control. Although the addition of the amino acids mixture alone showed little or no effect, the addition of calcium chloride and the amino acids mixture at the same time restored the growth of the yeast to the same level as that of the control. These findings indicated that S-PI affected the relationship of growth 


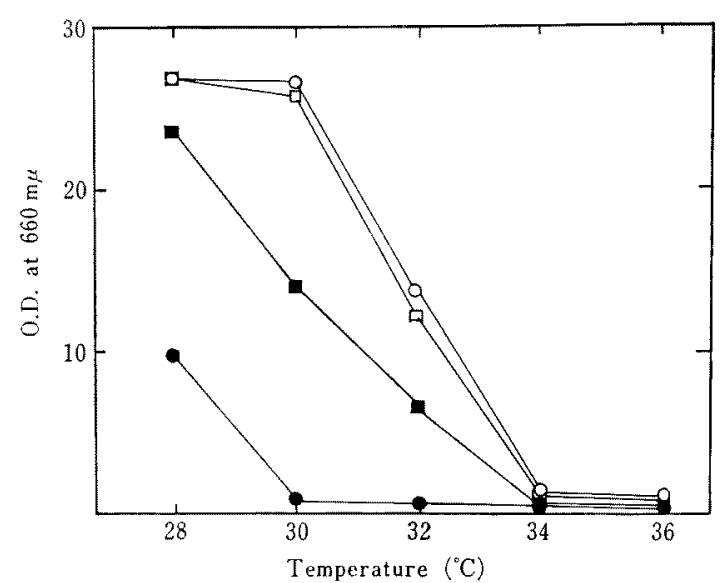

FIG. 2. Effect of Calcium Chloride and an Amino Acids Mixture on the Growth of Rhodotorula glutinis No. K-24 near the Maximum Growth Temperature in the Presence of S-PI.

The yeast cells were cultured at each temperature for $96 \mathrm{hr}$ and the O.D. at $660 \mathrm{~m} \mu$ was measured.

O-O $0 \mathrm{mg} \mathrm{S}-\mathrm{PI} / 100 \mathrm{ml}, \bullet 12 \mathrm{mg} \mathrm{S}-\mathrm{PI} /$ $100 \mathrm{ml}, 12 \mathrm{mg} \mathrm{S}-\mathrm{PI}$ and $20 \mathrm{mg} \mathrm{CaCl} \cdot 2 \mathrm{H}_{2} \mathrm{O} /$ $100 \mathrm{ml}, \square-\square 12 \mathrm{mg} \mathrm{S}-\mathrm{PI}, 20 \mathrm{mg} \quad \mathrm{CaCl}_{2} \cdot 2 \mathrm{H}_{2} \mathrm{O}$ and $1 \mathrm{~g}$ amino acids mixture*/100 $\mathrm{ml}$.

* Amino acid composition of this mixture was the same as that of soy bean casein.

and temperature by modifying the metabolism and that calcium ions and amino acids were closely related to the action of S-PI.

When this organism was cultured in the presence of S-PI, it was also observed that the formation of cellular pigmentation was affected. Therefore the isoprenoid content of the cell was determined according to the method of Kakutani. ${ }^{6}$ As shown in Table I, no effect on sterols and ubiquinone was observed in the presence of S-PI, but the intracellular contents of carotenes, i.e. phytoene, $\alpha$-and $\beta$-carotene and torulene, etc., were markedly decreased in almost the same ratio. These effects of S-PI on growth and the formation of carotene also varied, depending on the initial $\mathrm{pH}$ of the medium. The greatest effect was observed at about $\mathrm{pH} 3.0$ with a lesser effect at higher $\mathrm{pH}$. These effects of S-PI
Table I. Contents of Isoprenoids in Cells Grown in the Presence and Absence of S-PI

Cells were cultured for $96 \mathrm{hr}$ at $24^{\circ} \mathrm{C}$. The content of each isoprenoid was estimated by measuring its absorbancy after separation by column chromatography on alumina.

\begin{tabular}{lcc}
\hline Isoprenoid & \multicolumn{2}{c}{ Contents } \\
\cline { 2 - 3 } & $\begin{array}{c}\text { Control } \\
\mu \mathrm{g} / \mathrm{g} \\
\text { (dry weight) }\end{array}$ & $\begin{array}{c}\text { S-PI added } \\
\mu \mathrm{g} / \mathrm{g} \\
\text { (dry weight) }\end{array}$ \\
\hline Sterol & 2800 & 2900 \\
Ubiquinone & 650 & 470 \\
Carotene & & \\
Phytoene & 376 & 150 \\
$\alpha$-Carotene & 9 & 1 \\
$\beta$-Carotene & 60 & 19 \\
Unknown ${ }^{a)}$ & 56 & 18 \\
Torulene & 65 & 11 \\
\hline
\end{tabular}

a) The unknown carotene might be a mixture of $\gamma$-carotene, $\zeta$-carotene, and neurosporene. The content was calculated by assuming that $E_{1 \mathrm{~m}}^{1 \%}$ was 2000 .

on growth and the formation of carotene were widely observed in all of 43 strains of yeasts belonging to the genus Rhodotorula irrespective of their activities for acid protease formation.

In addition, the contents of lipids, carbohydrate and crude protein were determined. The results are shown in Table II. Although little or no effect on the concentration of carbohydrate was observed, the amounts of lipid decreased in the presence of S-PI. In particular, the amounts of phospholipid decreased.

On the other hand, nitrogen content, i.e. protein content, increased in the presence of S-PI. Taking into consideration the results that protein content of the cell increased 1.3 times and that growth increased 1.4 times, as mentioned above, the total protein of cells from an aliquot of broth increased to 1.9 times that of the control. These results indicate that S-PI affected the protein synthesis of this yeast. 
Table II. Principal Components of Cells of Rhodotorula glutinis No. K-24

Cells were cultured for $96 \mathrm{hr}$ at $24^{\circ} \mathrm{C}$ in the presence or absence of S-PI.

Nitrogen content was determined by the Kjeldahl metbod. Carbohydrate content was determined by the anthrone method. Lipid content was determined by extraction with chloroform-methanol $(1: 1 \mathrm{v} / \mathrm{v})$, followed by silica-gel chromatography.

\begin{tabular}{|c|c|c|c|c|}
\hline \multirow[b]{3}{*}{ Component } & \multicolumn{4}{|c|}{ Content } \\
\hline & Con & trol & S-PI & added \\
\hline & $\underset{\mathrm{mg} / 100}{\mathrm{mg}}$ & $\begin{array}{l}\mathrm{mg} / \mathrm{cells} \\
\text { obtained } \\
\text { from } \\
100 \mathrm{ml} \\
\text { broth }\end{array}$ & $\underset{\mathrm{mg}}{\mathrm{mg} / 100}$ & $\begin{array}{c}\mathrm{mg} / \text { cells } \\
\text { obtained } \\
\text { from } \\
100 \mathrm{ml} \\
\text { broth }\end{array}$ \\
\hline Nitrogen & 6.5 & 130 & 8.4 & 252 \\
\hline Carbohydrate & 24.5 & 490 & 22.5 & 675 \\
\hline Lipid & 15.6 & 312 & 8.6 & 256 \\
\hline Phospholipid & 3.12 & 62 & 0.86 & 26 \\
\hline Ash & 4.2 & 84 & 5.7 & 171 \\
\hline
\end{tabular}

When Cladosporium sp. No. 45-2 $2^{7}$ was cultured in an acidic medium, increase of growth and protein content was also observed. The growth increased $1.1 \sim 1.2$ times and the protein content of the mycelia increased to 1.3 times that of the control.

As described above, S-PI affected not only growth but also protein synthesis of yeast and fungi, and therefore S-PI, an acid protease inhibitor, seemed to have some effects as a physiologically active substance. Increase of growth and protein content of yeast by S-PI is particularly interesting, for S-PI might be applicable to increase the production of high protein fodder yeast.

\section{REFERENCES}

1) S. Murao and S. Satoi, Agr. Biol. Chem., 34, 1265 (1970).

2) M. Fukumura, S. Satoi, N. Kuwana and $S$. Murao, ibid., 35, 1310 (1971).

3) S. Murao and S. Satoi, ibid., 35, 1477 (1971).

4) S. Satoi and S. Murao, ibid., 35, 1482 (1971).

5) S. Murao, M. Kamada, T. Nakase, S. Ogura and K. Oda, Nippon Nogeikagaku Kaishi, 43, 167 (1972).

6) Y. Kakutani, J. Biochem., 61, 193 (1967).

7) S. Murao, S. Funakoshi and K. Oda, Agr. Biol. Chem., 36, 1327 (1971).

\section{Sawao Murao \\ Motoo AraI \\ Kunio NaKaHara \\ Masami TsUchiYA}

Department of Agricultural Chemistry,

College of Agriculture, University of

Osaka Prefecture, Sakai, Osaka, Japan

Received July 11, 1972 